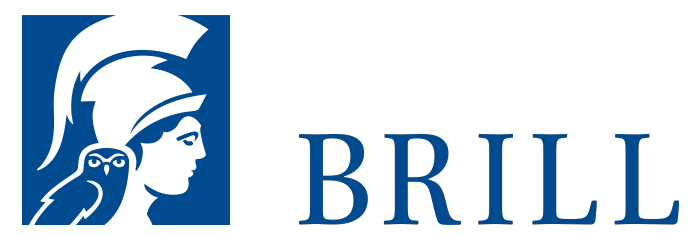

\title{
Silence in Modern Irish Literature
}

\section{Volume Editor: Michael McAteer}

Silence in Modern Irish Literature is the first book to focus exclusively on the treatment of silence in modern Irish literature. It reveals the wide spectrum of meanings that silence carries in modern Irish literature: a mark of historical loss, a form of resistance to authority, a force of social oppression, a testimony to the unspeakable, an expression of desire, a style of contemplation. This volume addresses silence in psychological, ethical, topographical, spiritual and aesthetic terms in works by a range of major authors including Yeats, Joyce, Beckett, Bowen and Friel.

\section{Readership}

All interested in modern Irish literature, European Modernist literature (Yeats, Joyce, Beckett, Flann O'Brien), Modern Drama, Postcolonial Studies, Gender Studies, and anyone concerned with psychoanalytical and philosophical approaches to literature.

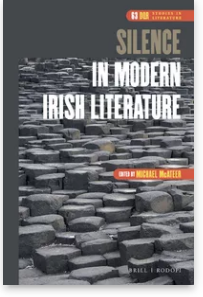

Pages: Approx. $230 \mathrm{pp}$.

Language:

English

Subjects:

Criticism \&

Theory,

Literature and

Cultural Studies, Drama \&

Theatre Studies, Art History, English \&

Anglophone, Literature and Cultural Studies Publisher: Brill

Series:

DQR Studies in Literature

Online, Volume: 63

DQR Studies in

Literature,

Volume: 63

E-Book (PDF)

Released online: 21 Aug 2017

ISBN: 978-90-

04-34274-3

List price

USD \$146.0o

Hardback 
Publication date:

o6 Apr 2017

Michael McAteer, Ph.D. (1998), Queen's University Belfast, is Associate Professor of English at Pázmány Péter University, Budapest. He has published extensively on Irish Literature, including Standish O'Grady, AE, Yeats (Irish Academic P, 2002); Yeats and European Drama (Cambridge UP, 2010).

For more information see brill.com

Order information: Order online at brill.com +44330 333 o049 | customerservices@brill.com Submission information: brill.com/authors

Titles published by Brill | Fink, Brill | mentis or Brill | Schöningh: +49(o)71 5413279216 | brill@brocom.de

ISBN: $978-90-$

04-34273-6

List price

USD \$146.oo 